\title{
The Influence of Chromium Impurity on the Spectral Characteristics of $\mathrm{ZnWO}_{4}$ Crystals
}

\author{
Stepan Novosad \\ Scientific-technical and Educational Centre \\ of low Temperature Studies \\ Ivan Franko National university of Lviv \\ Lviv, Ukraine \\ ss_novosad@ukr.net \\ Iryna Novosad \\ dept. of Physics \\ Ivan Franko National university of Lviv \\ Lviv, Ukraine \\ irenanovosad@gmail.com
}

\author{
Ludmyla Kostyk \\ dept. of Electronics and Computer Technologies \\ Ivan Franko National university of Lviv \\ Lviv, Ukraine \\ kostyk@electronics.lnu.edu.ua
}

\author{
Mykola Rudko \\ Scientific-technical and Educational Centre \\ of low Temperature Studies \\ Ivan Franko National university of Lviv \\ Lviv, Ukraine \\ rudko_mykola@ukr.net
}

\begin{abstract}
The absorption, excitation, and emission spectra under photo- and $\mathrm{X}$-ray excitation of $\mathrm{ZnWO}, \mathrm{ZnWO}_{4}: \mathrm{Cr}^{3+}$ zinc tungstate crystals have been investigated. The charge trapping and the radiative thermally stimulated recombination processes in $\mathrm{ZnWO}_{4}$ involve six trapping states at at 107, 129, 152, $170 \mathrm{~K}$ and $200,235 \mathrm{~K}$. The activation energies of traps which are responsible for appearance of TSL in the region $80-300 \mathrm{~K}$ were estimated.
\end{abstract}

Index Terms-78.55.Hx; $\quad$ 78.60.Kn; 78.70.Ens-Keywordsphoto- and X-ray luminescence; thermostimulated luminescence; $\mathrm{ZnWO}_{4}$

\section{INTRODUCTION}

Zinc tungstate (space group $P 2 / c$ ) with a width of the band gap of $\mathrm{E}_{\mathrm{g}} \approx 4.6 \mathrm{eV}$ has a monoclinic crystalline structure of wolframite-type [1]. High energy resolution, low level of radioactive background and good signal resolution by particle types make $\mathrm{ZnWO}_{4}$ suitable for searching for double beta decay of isotopes of zinc and tungsten, study of alpha decays of tungsten isotopes, as well as for use as a dark matter particle detector [2-4]. Crystals of zinc tungstate have a smaller light yield than the most effective crystals on the basis of alkali metal iodides, but they are not hygroscopic, easy to preparation, can be obtained as nanosized crystals. The main disadvantage of these materials is the strong dependence of the quality of crystals on the presence of impurities and growing conditions $[1,5]$. The slow decay of scintillation due to the presence of structural and impurity defects limits the using of the $\mathrm{ZnWO}_{4}$ scintillator in cases where large registration speeds are required [5].

The development of science and technique in different areas associated with the using the luminescent materials, led to an increase works on the synthesis and study of crystalline phosphors doped with the impurities of iron group ions [6-8]. On other hand, the crystals doped with ions of transition metal are widely used as effective materials for solid state lasers. In spite of many studies devoted to research of the $\mathrm{ZnWO}_{4}$ crystals, activated by the ions of transitional metals, by the $\mathrm{Cr}$ ions in particular, nature of recombination luminescence and mechanisms of thermoactivation processes in these materials have not been studied sufficiently.

Basing on the literature data, the results of the spectralluminescence characteristics of $\mathrm{ZnWO}_{4}$ crystals and $\mathrm{ZnWO}_{4}: \mathrm{Cr}^{3+}$ samples after their long-term storage under laboratory conditions in an air atmosphere are analyzed in the paper.

\section{EXPERIMENTAL}

For the present investigation $\mathrm{ZnWO}_{4}$ single crystals were grown from platinum crucibles by the Czochralski method [1]. The impurities were entered as $\mathrm{Cr}_{2} \mathrm{O}_{3}$ oxide. The content of $\mathrm{Cr}$ impurity was $\sim 0.5 \mathrm{~mol} \%$. Samples in a thickness of 0.5 $1.0 \mathrm{~mm}$ were obtained by cleaving the crystal in a (100) plane. Chromium $3 \mathrm{~d}^{3}$ ions replace two-valent cations $\mathrm{Me}^{2+}$ in a regular lattice and occupy a distorted octahedron formed by oxygen ions in $\mathrm{ZnWO}_{4}$ crystals. Since the crystals doped with $\mathrm{Cr}^{3+}$ ions were grown without the introduction of an ion compensator, the problem of compensating for excessive charge could be solved by the creation of one vacancy $\mathrm{Zn}^{2+}$ $\left(V_{\mathrm{Zn}}\right)$ on two $\mathrm{Cr}^{3+}$ ions. Local charge compensation is carried out by the vacancy of zinc $\left(V_{Z n}\right)$ with a localized on it one hole corresponding to the formation of a neutral associate.

Spectroscopic investigation of samples in the case of X-ray excitation was carried out in helium cryostat with the using a setup based on the MDR-12 diffraction monochromator. Scanning and recording of the X-ray luminescence spectra 
were carried out with a computerized system. Emission in the spectral region $350-850 \mathrm{~nm}$ was measured in single photon mode using. FEU-51 photomultiplier. X-ray excitation was provided by a URS-55A X-ray generator and Mo-target BSV-2 X-ray tube (U=45 kV, I=10 mA) through the beryllium window of the cryostat. The curves of thermostimulated luminescence (TSL) were recorded in the integral mode under linear heating of samples at a rate $\sim 0.07 \mathrm{~K} / \mathrm{s}$. The temperature was set with the accuracy of $0.1 \mathrm{~K}$ in the range of $80-500 \mathrm{~K}$. Investigation of optical-luminescence characteristics of crystals in the case of optical excitation at $300 \mathrm{~K}$ was carried out on a spectrofluorimeter CM 2203. The device provided a possibility to measure the spectra of excitation and luminescence in the spectral region of $200-820 \mathrm{~nm}$.

\section{RESULTS AND DISCUSSION}

Absorption spectra of $\mathrm{ZnWO}_{4}$ tungstate are characterized by a sharp increase of the absorption coefficient in the region of the fundamental absorption edge [1]. The absorption spectra in the visible region of the activated with $\mathrm{Cr}^{3+}$ crystals are represented by wide bands at $\sim 510$ and $715 \mathrm{~nm}$, due to the ${ }^{4} A_{2} \rightarrow{ }^{4} T_{1}$ and ${ }^{4} A_{2} \rightarrow{ }^{4} T_{2}$ transitions in $\mathrm{Cr}^{3+}$ ions, respectively. Activator absorption band with maximum at 340-345 nm which associated with the ${ }^{4} A_{2} \rightarrow{ }^{4} T_{1}\left({ }^{4} P\right)$ transitions is observed in the spectral range near matrix absorption edge. Emission spectrum of $\mathrm{ZnWO}_{4}$ at $90 \mathrm{~K}$ is represented by a nonelementary band with a maximum near $480 \mathrm{~nm}$ (Fig. 1).

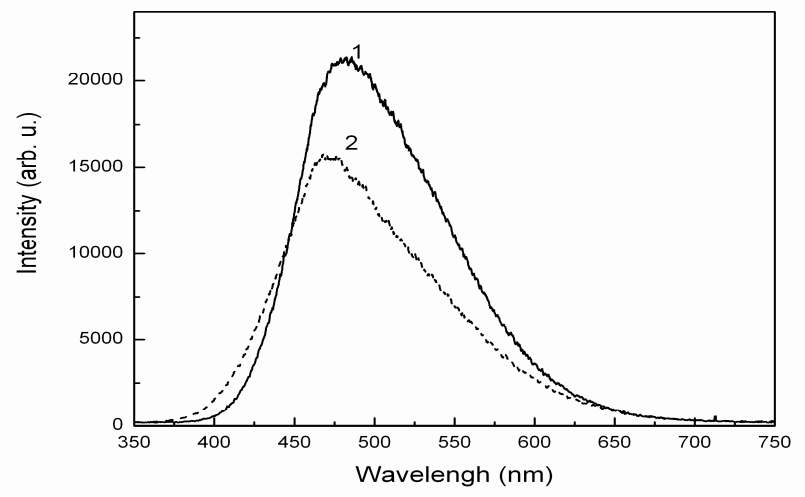

Figure 1. XRL spectra of $\mathrm{ZnWO}_{4}$ crystals at 90 (1) and $300 \mathrm{~K}$ (2).

At this temperature the $\mathrm{ZnWO}_{4}$ is characterized by an inertial rise of steady-state X-ray luminescence (XRL). The previous X-ray irradiation of the sample for a further 90 minutes leads to a slight shift of maximum of the emission spectrum to short-wave range. With an increasing temperature up to $300 \mathrm{~K}$, the luminescence intensity decreases by $30 \%$, there is a decrease in the half-width of the spectrum and a shift of its maximum to $470 \mathrm{~nm}$. The spectra of XRL are characterized by a superposition of several partially overlapping basic elementary bands with maxima of about 440 $\mathrm{nm}(2.84 \mathrm{eV}), 480 \mathrm{~nm}(2.59 \mathrm{eV})$ and a relatively weak band of $600 \mathrm{~nm}(2.04 \mathrm{eV})$. In the case of optical excitation of $\mathrm{ZnWO}_{4}$, a $460 \mathrm{~nm}$ wideband luminescence, which is a superposition of several bands, is also observed [9]. The shift of the X-ray and photoluminescence spectra relative to each other is attributed to the change in the ratio of the relative contribution of the elementary emission bands by reducing the intensity of the band $480 \mathrm{~nm}$ in the case of high-energy excitation. The 480 $\mathrm{nm}$ intrinsic luminescence of $\mathrm{ZnWO}_{4}$ is excited in a main band with maximum of about $270 \mathrm{~nm}$ and on a bend at $310 \mathrm{~nm}$ at $300 \mathrm{~K}$. The excitation spectrum of the matrix emission in $\mathrm{ZnWO}_{4}: \mathrm{Cr}$ is characterized by a maximum in the region of the long-wave edge of the own absorption.

Doping $\mathrm{ZnWO}_{4}$ with $\mathrm{Cr}^{3+}$ ions leads to a decrease of the matrix luminescence intensity by approximately an order of magnitude, while weakly affects the spectral composition of the matrix emission. A significant decrease of matrix luminescence intensity in the doped crystals can be explained by the absorption of this emission by $\mathrm{Cr}^{3+}$ ions and the redistribution of the energy of radiative transitions in favor of activating centers luminescence with a maximum of about 900-1000 nm (transition ${ }^{4} T_{2} \rightarrow{ }^{4} A_{2}$ ) [9]. Rise of the activator content is accompanied by an increase of the luminescence intensity of $\mathrm{ZnWO}_{4}$ : $\mathrm{Cr}^{3+}$ in long wave range with the decay time $\sim 10^{-5} \mathrm{~s}[1]$.

From the analysis of the obtained experimental results and the literature data, it follows that the long-term storage of samples does not affect the emission processes in zinc tungstate. A typical intrinsic luminescence band with a maximum of $480 \mathrm{~nm}$, which is dominant in the XRL spectrum, is caused by the radiative decay of self-trapped excitons of oxyanion complex $\mathrm{WO}^{6-}$. Under excitation by optical illumination with a wavelength of $310 \mathrm{~nm}$, optical transitions that are associated with the transfer of charge from oxygen to the conduction band on the tungsten states of the $\mathrm{ZnWO}_{4}$ crystals are predominantly occurring, which leads to the creation the self-trapped excitons on these complexes. In the case of excitation in the fundamental absorption band by photons with a wavelength of about $270 \mathrm{~nm}$, the luminescence occurs with previous binding the electron and hole in exciton. Observed similar features in the spectral characteristics of luminescence of the investigated $\mathrm{ZnWO}_{4}$ crystals and $\mathrm{CdWO}_{4}$ isostructural crystals [10] make it possible to assume that elementary Gaussian bands with a maximum of about 440 and $600 \mathrm{~nm}$ are related to radiation in oxyanion groups located near defective complexes containing cationic and anion vacancies, respectively.

The stage of transfer of separated electrons and holes to the luminescence centers depends on the presence of traps in the forbidden gap and significantly affects the scintillation mechanism. Studies have shown that the intensity of the peaks and the shape of the TSL curves are quite sensitive to the conditions for the preparation of $\mathrm{ZnWO}_{4}$ crystals and the heating rate of the samples. Characteristic is that this material stores light sums mainly on the deep levels responsible for the peaks of TSL above $180 \mathrm{~K}$. The presence of traps, which manifests itself at high-temperature peaks of TSL, is due to the slow components of the $\mathrm{ZnWO}_{4}$ glow at $300 \mathrm{~K}$ [5].

The TSL curve after X-ray excitation of $\mathrm{ZnWO}_{4}$ crystal at a temperature of $90 \mathrm{~K}$ for a 5 minutes and a further heating rate $\beta$ of sample $\sim 0.07 \mathrm{~K}$ is characterized by a superposition of weak peaks at $107,129,152,170 \mathrm{~K}$ and peaks $200,235 \mathrm{~K}$ 
with a higher intensity (Fig. 2). Increasing the time of the previous X-ray excitation of the sample to 30 minutes leads to an increase of TSL intensity approximately in 3.5 times, while not affecting the position of the peaks.

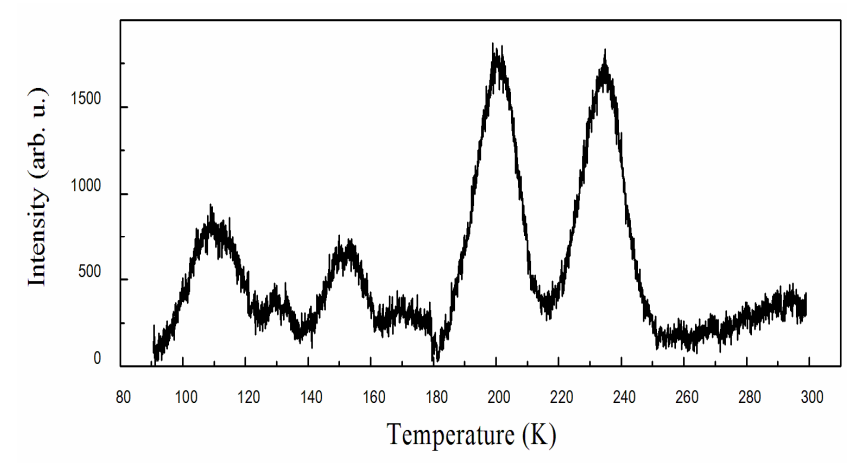

Figure 2. TSL curve of the crystal $\mathrm{ZnWO}_{4}$ after X-ray excitation at $90 \mathrm{~K}$.

In [1] it was assumed that the lowest-temperature TSL peaks of the $\mathrm{ZnWO}_{4}$ crystals, on the one hand, and the highest-temperature peaks on the other hand, have opposite signs of the relaxation mechanism. It is established that the peaks of thermoluminescence in the 80-200 $\mathrm{K}$ range in $\mathrm{ZnWO}_{4}$ have a spectral composition similar to the spectral composition of the steady-state luminescence. The highesttemperature peaks (above $200 \mathrm{~K}$ ) exhibit long-wavelength thermoluminescence with a maximum at $620 \mathrm{~nm}$. The identity of the spectral composition of the low-temperature TSL peaks and the XRL spectra obviously indicates that the steady-state $\mathrm{XRL}$ is the result of the recombination of holes with electrons at electron trap levels. The concentration of capture centers responsible for high-temperature peaks is definitely regulated by the presence of defects (mainly vacancies) in the cation sublattice [1].

All four low-temperature weakly intense peaks are partially overlapped. Therefore, an approximate formula was used to estimate the depth of the levels responsible for these peaks $E(\mathrm{eV})=T_{\max }(\mathrm{K}) / 540$ [11]. According to this formula it is determined that peaks at 107, 129, 152 та $170 \mathrm{~K}$ correspond to activation energies $E_{a} \approx 0.20,0.24,0.28$ and $0.31 \mathrm{eV}$, respectively. The analysis of the shape of TSL curve showed that for the dominant peaks at 200 and $235 \mathrm{~K}$, the true ratio $T_{\mathrm{h}}-T_{\mathrm{m}}<\mathrm{T}_{\mathrm{m}}-\mathrm{T}_{\mathrm{l}}$, where $\mathrm{T}_{\mathrm{l}}, \mathrm{T}_{\mathrm{h}}$ is the temperature corresponding to half the peak height at the low temperature and hightemperature branches; $\mathrm{T}_{\mathrm{m}}$ - position of the maximum of the peak on the TSL curve. Assuming that these peaks are elementary and $\Delta=T_{\mathrm{h}}-T_{1}$ and $\delta=T_{\mathrm{h}}-T_{\mathrm{m}}$, determined parameters of asymmetry of peaks (form factor) $\mu_{\mathrm{g}}=\delta / \Delta$. For both peaks values are obtained $\mu_{\mathrm{g}} \approx 0.46$ and 0.41 , which corresponds to the kinetics of the first order [12] and the process of release of the stored light takes place in monomolecular kinetics.

To estimate the depth of traps for a linear case of kinetics at $A_{p}>A_{c}$ used the proposed by Ch.B. Lushchik [13] expression: $E=k_{B} T_{m}{ }^{2} / \delta\left(k_{B}-\right.$ Boltzmann constant; $A_{c}-$ probability of capture, $A_{p}$ - probability of recombination). The thermo activating parameters of the dominant peaks were also calculated by the formula [12]: $E=2,52 k_{\mathrm{B}} T_{m}{ }^{2} / \Delta-2 k_{\mathrm{B}} T_{m}$. The values of the thermal depth of the traps that are related to the dominant peaks obtained by different methods were averaged. It was established that the peaks of TSL at 200 and $235 \mathrm{~K}$ correspond to activation energies $\mathrm{E} \approx 0.48$ and $0.68 \mathrm{eV}$ [1]. The doping of $\mathrm{ZnWO}_{4}$ crystal by chromium impurity leads to a significant reducing of thermoluminescence. A weak peak at $107 \mathrm{~K}$ is recorded on the TSL curve of the $\mathrm{ZnWO}_{4}: \mathrm{Cr}^{3+}$ crystal. Due to its ability to change the valence state, the chromium impurity is an effective center for capturing the nonequilibrium charge carriers [14]. The recombination of a free electron with centers of $\mathrm{Cr}^{4+}$, or a hole localized on a zinc vacancy, converts $\mathrm{Cr}^{3+}$ into an excited state $\left(\mathrm{Cr}^{3+}\right)^{*}$. The transition $\left(\mathrm{Cr}^{3+}\right)^{*}$ to the ground state is accompanied by the activator emission in the long-wavelength region of the activator emission in the long-wavelength region of the spectrum with a maximum of about $900-1000 \mathrm{~nm}$, which is not recorded when measuring the TSL curves.

\section{REFERENCES}

[1] Л. Н. Лимаренко, А. Е. Носенко, М. В. Пашковский и Д.-Л. Л. Футорский, "Влияние структурных дефектов на физические свойства вольфраматов”, Львов: Вища школа, 1978, с. 67-160.

[2] P. Belli, R. Bernabei, F. Cappella [et al.], "Search for $2 \beta$ processes in ${ }^{64} \mathrm{Zn}$ with the help of $\mathrm{ZnWO}_{4}$ crystal scintillator", Phys. Lett ., vol. 658, pp.193-197, 2008.

[3] I. Bavykina, G. Angloher, D. Hauff [et al.], "Development of cryogenic phonon detectors based on $\mathrm{CaMoO}_{4}$ and $\mathrm{ZnWO}_{4}$ scintillating crystals for direct dark matter search experiments", Opt. Materials, vol. 31, pp. 1382-1387, 2009.

[4] L. L. Nagornaya, A. M. Dubovik, Yu. Ya. Vostretsov [et al.], "Growth of $\mathrm{ZnWO}_{4}$ crystal scintillators for high sensitivity $2 \beta$ experiments", IEEE Trans. On Nuclear Science, vol. 55, pp.1469-72, 2008.

[5] Б. В. Гринев, В. Д. Рыжиков, В. П. Семиноженко, “Сцинтилляционные детекторы и системы контроля радиации на их основе”, Киев: Наукова Думка, 2007.

[6] L. Grigorjeva, V. Pankratov, D. Millers [et al.], "Time - resolved spectroscopy in $\mathrm{ZnWO}_{4}$ and $\mathrm{ZnWO}_{4}: \mathrm{Fe}$ ", Radiation Effects and Defects in Solids, vol. 158, pp. 135-137, 2003.

[7] A. Kotlov, L. Jonsson, M. Kirm [et al.], "Luminescence study of selftrapped holes in pure and Fe- or Mo-doped $\mathrm{ZnWO}_{4}$ crystals", Rad. Measur., vol. 38, pp. 715-718, 2004.

[8] T. N. Nikolaenko, Yu. A. Hizhnyi, S. G. Nedilk, "VUV synchrotron studies of the effect of $\mathrm{Cr}$ doping on the luminescence properties of $\mathrm{ZnWO}_{4}$ crystals", Highlights and HASYLAB Annual Report, pp. 1-2, 2010.

[9] Л. Костик, А. Лучечко, С. Новосад, “Вплив домішки хрому на люмінесцентні властивості кристалів $\mathrm{ZnWO}_{4}$ ”, Електроніка i інформаційні технології, вип. 5, с. 53-64, 2015.

[10] И. А. Тупицына, Б. В. Гринев, Л. Л. Нагорная, “Влияние дефектов на радиационно-индуцированные процессы в сцинтилляционных кристаллах вольфрамата кадмия. Вопросы атомной науки и техники", вып. 4-2, с. 145-149, 2009.

[11] Ю. В. Воронов, Ю. П. Тимофеев, “Термовысвечивание неактивированного сульфида цынка при электронном возбуждении", Изв. АН СССР. Сер. физ., вып. 33, с. 951-960, 1969.

[12] И. Н. Огородников, М. Д. Петренко, В. Ю. Иванов, "Низкотемпературная люминесценция и термостимулированная люминесценция монокристаллов $\mathrm{BeO}: \mathrm{Mg} ”$, Физика твердого тела, вып. 60, с. 132-144, 2018.

[13] Ч. Б. Лущик, “Исследование центров захвата в щелочно-галоидных кристаллофосфорах”, Труды ИФА АН ЭССР, Вып. 3. с. 3-5, 1955.

[14] А. С. Марфунин, “Спектроскопия, люминесценция и радиационные центры в минералах”, М.: Недра, 1975. 